${ }^{1}$ Sakarya Üniversitesi Eğitim ve Araştırma Hastanesi, Biyokimya, Sakarya e-posta: drmozdin33@gmail.com ORCID: 0000-0030-3077-7171

Atıf İçin: Mehmet ÖZDiN, Atopik Dermatiti Olan Çocuklarda Hematolojik ve Alerjik Değerler Arasındaki illişki, Balıkesir Medical Journal, 2020;4(3):1-6

Başvuru Tarihi: 30.06.2020

Kabul Tarihi: 23.11.2020 Yayınlanma Tarihi: 27.11.2020

Sorumlu Yazar: Mehmet ÖZDiN, Sakarya Üniversitesi Eğitim ve Araştırma Hastanesi, Biyokimya, Sakarya e-posta: drmozdin33@gmail.com

\title{
Atopik Dermatiti Olan Çocuklarda Hematolojik ve Alerjik Değerler Arasındaki iliş̧ki
}

\author{
The Relationship Between Hematological and Allergic Values in \\ Children with Atopic Dermatitis
}

\author{
Mehmet Özdin ${ }^{1}$
}

öz

Amaç: Bu çalışmada amacımız; Sakarya Üniversitesi Eğitim ve Araştırma Hastanesi (SÜEAH) Pediatrik Dermatoloji Polikliniklerine müracaat eden pediatrik yaş grubunda Atopik Dermatit (AD) hastalarında, periferik kandan ölçülebilen nötrofil lenfosit oranı (NLO), trombosit lenfosit oranı (TLO), eozinofil lenfosit oranı (ELO) ile serum total immün globobülin $E$ (T-IgE) değerleri ve kan eozinofil sayısını tespit etmek AD ile bu parametreler arasındaki ilişkiyi araştırmaktır.

Gereç ve Yöntemler: Çalışmaya dahil ettiğimiz hastalara ait veriler 01.01.2018 ile 31.10.2019 tarihleri arasında müracaat eden $A D$ hastalarından hastane bilgi yönetimi sistemi (HBYS) üzerinden retrospektif olarak elde edildi. Kontrol grubuna alerjik hastalığı, enfeksiyonu veya kronik bir hastalığı olanlar dahil edilmedi.

Bulgular: Çalışma kriterlerine uyan $30 \mathrm{AD}$ hastasının 8 kız, 22 erkek olup, yaş ortalaması $9.33 \pm 5.84$ olarak tespit edildi. Kontrol grubunda 30 olgunun 12 'si kız, 18'i erkek olmak üzere yaş ortalaması $10.69 \pm 4.69$ olarak belirlendi. AD hastalarının T-lgE değerleri $304.48 \pm 25.81 \mathrm{IU} / \mathrm{mL}$, eozinofil düzeyleri ortalama $1.39 \pm 0.29 \mathrm{~K} / \mathrm{uL}$, NLO $2.23 \pm 1.19$, TLO 123.69 \pm 41.99 , ELO $0.133 \pm 0.111$ olarak tespit edildi. Kontrol grubunun T-IgE değerleri $41.03 \pm 6.18 \mathrm{IU} / \mathrm{mL}$, eozinofil düzeyleri ortalama $0.39 \pm 0.09$ $\mathrm{K} / \mathrm{UL}$, NLO $1.73 \pm 0.61,107.66 \pm 35.30$, ELO $0.071 \pm 0.049$ olarak tespit edildi. AD hastaları ile kontrol grubu istatistiksel olarak karşılaştıııldı̆̆ında T-IgE, Eozinofil, NLO, ELO değerleri arasında $(p<0.05)$, TLO değerleri ise $(p>0.05)$ olarak tespit edildi.

Sonuç: Çalışmamızda AD hastalarında NLO, TLO, ELO ile T-IgE değerleri ile kan eozinofil düzeyleri yüksek bulunmuştur. Bu parametrelerin bu hastalı̆ı̆ teşhis ve takibinde önemli olduğunu ortaya koymaktadır. Bu değerlerin yüksek saptanması, daha sonraki çalışmalarda bu değerlerin referans olarak alınabilmesine katkı sağlayacaktır.

Anahtar Kelimeler: atopik dermatit; total IgE değerleri; nötrofil lenfosit oranı

\section{ABSTRACT}

Aim: Our aim in this study; In Atopic Dermatitis (AD), patients in the pediatric age group who applied to the Pediatric Dermatology Polyclinics of Sakarya University Training and Research Hospital (SUTRH), to determine neutrophil lymphocyte ratio (NLO), platelet lymphocyte ratio (TLO), eosinophil lymphocyte ratio (ELO) and serum total immune globobulin E (T$\mathrm{IgE}$ ) values and blood eosinophil count to investigate the relationship between $A D$ and these parameters.

Materials and Methods: The data of the patients we included in the study were obtained retrospectively from the AD patients who applied between 01.01.2018 and 31.10.2019 through the hospital information management system (HIMS). Those with allergic disease, infection or chronic disease were not included in the control group.

Results: Of the $30 \mathrm{AD}$ patients who met the study criteria, 8 were girls and 22 were boys, with an average age of $9.33 \pm$ 5.84. In the control group, the average age of the patients was 12.6 girls and 18 boys, $10.69 \pm 4.69$. T-IgE values of $A D$ patients were determined as $304.48 \pm 25.81 \mathrm{IU} / \mathrm{mL}$, eosinophil levels were $1.39 \pm 0.29 \mathrm{~K} / \mathrm{uL}$, NLO $2.23 \pm 1.19$, TLO 123.69 \pm 41.99 , ELO 0.133 \pm 0.111 . T-IgE values of the control group were determined as $41.03 \pm 6.18 \mathrm{IU} / \mathrm{mL}$, eosinophil levels on average $0.39 \pm 0.09 \mathrm{~K} / \mathrm{UL}$, NLO $1.73 \pm 0.61,107.66 \pm 35.30$, ELO $0.071 \pm 0.049$. When AD patients and control groups were compared statistically, T-IgE, Eosinophil, NLO, ELO values were determined as $(p<0.05)$ and TLO values as $(p>0.05)$.

Conclusion: In our study, NLR, TLR, ELR and T-IgE values and blood eosinophil levels were found high in AD patients. It reveals that these parameters are important in the diagnosis and follow-up of this disease. High determination of these values will contribute to the reference of these values in future studies.

Keywords: atopic dermatitis; total IgE levels; neutrophil lymphocyte ratio 
Atopik Dermatit $(A D)$, bebeklik ve çocukluk çağında insidansı artma gösteren pediatrik hastalıktır. Allerji ve immünoloji kliniklerinde çok sık rastlanan, tekrarlayan ataklarla seyreden, kronik gidişli, oluşumlarında immünolojik mekanizmaların önemli derecede rol oynadığı, pruritus ile karakterize bir grup dermatozdur $(1,2)$. $A D$, total ve antijene spesifik IgE'lerin aşıı üretimi ile birlikte, dolaşımdaki eozinofil sayısının ve eozinofil kemotaksisinin artmasıyla da karakterizedir. Eozinofil kökenli katyonik proteinlerin serum ve dokuda artmıs olması da hastalı̆ın patogenezinde eozinofillerin büyük bir rolü olduğunu düşündürmektedir (2). Son yıllarda $A D$ yaygınlı̆̆ında 2-3 kat artış görüldüğü ve artışın devam ettiği bildirilmektedir. Hastalığın prevelansı son 40 yıl içinde gittikçe artmaktadır (3). Yapılan hayvan çalışmalarında, burundan alınan alerjenlerle karşılaştırıldığında, deriden verilen antijenlerle IgE seviyeleri 100 ile 1000 kat daha yüksek bulunmuştur (4). Nötrofil, lenfosit ve trombosit enflamasyon görüldüğü zamanlarda görev alan önemli kan parametreleridir. NLO ve TLO değerleri kolayca hesaplanabilen ve maliyetleri oldukça düşük testlerdir. Sistemik enflamasyon varlığını gösteren yeni bir markır olarak NLO'nun kullanılması önerilmiştir (5). Erlich tarafından 1879 yılında eozinofillerin tanımlanmasından günümüze enflamatuar olaylarda rolleri olduğu bilinmektedir. Özellike paraziter enfeksiyonlarda konakçı yanıtını oluşturan en önemli hücrelerdir. Eozinofiller ayrıca eozinofilik katyonik protein (EKP) ve majör temel protein (MTP) ihtiva etmektedir. Eozinofiller bu iki protein ve diğer granüller sayesinde başta astım, (6) olmak üzere $A D$, (7) bazı alerjik göz hastalıklarında ve rinitte (8) enflamatuar reaksiyonlar meydana getirir. AKP özellikle enflamasyonun önemli bir etkileyicisi olup bazı hücrelere karşı potansiyel bir toksin ve çeşitli alerjik hastalıkların aktive olmasında etkili bir proteindir (9). Bu çalışmada amacımız AD'li hastalarda Total IgE (T-IgE), eozinofil, NLO, TLO, ELO düzeyinin saptanması ve daha sonraki çalışmalarda bu sonuçların referans olarak alınabilmesini sağlamaktır.

\section{GEREÇ VE YÖNTEMLER}

Sakarya Üniversitesi Eğitim ve Araştırma Hastanesi (SÜEAH) Pediatrik Dermatoloji Polikliniklerine 01.01.2018 ile 31.10.2019 tarihleri arasında müracaat eden $A D$ tanısı alan 8 kız, 22 erkek olmak üzere $30 A D$ hastası ile kontrol grubunu oluşturan 30 olgunun 12'si kız, 18'i erkek olup bu kişilere ait bilgiler Hastane Bilgi Yönetimi Sistemi (HBYS) üzerinden retrospektif olarak elde edildi. Kontrol grubuna alerjik hastalığı, enfeksiyonu veya kronik bir hastalığı olanlar dâhil edilmedi. Hasta ve kontrol grubu aralarındaki ilişki ve farklar araştıııld.

Nötrofil, lenfosit, trombosit ve eozinofil testleri, CELL-DYN 3700 (ABBOTT, USA) cihazında, T-IgE testleri ise SIEMENS BN II cihazında çalışılmıştır.

Çalışmalardan elde edilen verilerin istatistiksel analizi için, IBM SPSS Windows 20.0 (SPSS, Chicago, USA) proğramı kullanılarak yapıldı. Gruplar arası karşılaştırmalarda student $t$ testi kullanılmışıı. Veriler ortalama \pm standart sapma olarak ifade edildi. Sonuçların tümünde $p<0.05$ değerleri anlamlı olarak kabul edilmiştir.

Çalışmamızın etik kurul raporu Sakarya Üniversitesi, Tıp fakültesi, Etik Kurulunda alınmıştır. Tarih ve sayısı; 03/05/2019 ve E.5551 'dir. 


\section{BULGULAR}

Incelenen AD hastasının yaş ortalaması 9.33 \pm 5.84 yıl olarak tespit edildi. Kontrol grubunun da yaş ortalaması 10.69 \pm 4.69 yıl olarak belirlendi. Çalışmada AD hastalarının T-lgE değerleri 304.48 $\pm 25.81 \mathrm{IU} / \mathrm{mL}$ iken kontrol grubunun T-IgE değerleri $41.03 \pm 6.18 \mathrm{IU} / \mathrm{mL}$ olarak tespit edildi. Hastaların eozinofil düzeyleri ortalama $1.39 \pm 0.29 \mathrm{~K} / \mathrm{uL}$ iken kontrol grubunun eozinofil düzeyleri ortalama $0.39 \pm 0.09 \mathrm{~K} / \mathrm{uL}$ olarak belirlendi. Hasta grubunun NLO 2.23 \pm 1.19 iken kontrol grubunun NLO $1.73 \pm 0.61$ olarak tespit edildi. Hasta grubunun TLO

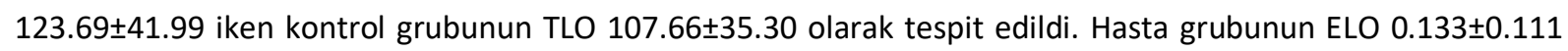
iken kontrol grubunun ELO $0.071 \pm 0.049$ olarak tespit edildi. İstatistiksel olarak hasta ile kontrol grubu karşılaştırıldığında T-IgE, Eozinofil, NLO, ELO değerleri arasında $(p<0.05)$, TLO değerleri ise $(p>0.05)$ olarak tespit edildi. Veriler Tablo 1'de sunulmuştur.

\begin{tabular}{|l|l|l|l|}
\hline & $\begin{array}{l}\text { Hasta }(\mathbf{n = 3 0}) \\
\text { (ortalama } \pm \text { SE) }\end{array}$ & $\begin{array}{l}\text { Kontrol }(\mathbf{n = 3 0}) \\
\text { (ortalama } \pm \text { SE) }\end{array}$ & $\begin{array}{l}\mathbf{p} \\
\text { değeri }\end{array}$ \\
\hline Yaş & $9,33 \pm 5,84$ & $10,69 \pm 4,69$ & \\
\hline Total IgE (IU/mL) & $304.48 \pm 25.81$ & $41.03 \pm 6.18$ & $<0.05$ \\
\hline $\begin{array}{l}\text { Eosinofil } \\
\text { (K/uL) }\end{array}$ & $1.39 \pm 0.29$ & $0.39 \pm 0.09$ & $<0.05$ \\
\hline NLO & $2,23 \pm 1,19$ & $1,73 \pm 0,61$ & $<0.05$ \\
\hline TLO & $123,69 \pm 41,99$ & $107,66 \pm 35,30$ & $>0.05$ \\
\hline ELO & $0,133 \pm 0,111$ & $0,071 \pm 0,049$ & $<0.05$ \\
\hline
\end{tabular}

Tablo 1. Atopik Dermatitli hastalar ile kontrol grubuna ait veriler

\section{TARTIŞMA}

AD’te genetik faktörlerin etkisi araştırılmıştır. Bu doğrultuda yapılan çalışmalarda genetik faktörlerin rolü ikiz çalışmalarıyla açıkça gösterilmiştir; AD oranı monozigot ikizlerde \%77, dizigotik ikizlerde ise \%15 olarak tespit edilmiştir. AD’de pozitif aile öyküsünün majör risk faktörlerinden birisi olarak kabul edilmesi genetik faktörlerin önemini vurgulamaktadır (10). Ülkemizde yapılan çok merkezli çalışmanın sonucunda da $A D^{\prime} l i$ hastalarda ailede allerji öyküsü \%56,5 olarak bildirilmiştir (11). Alerjik deri hastalıkları ile IgE düzeyleri ile eozinofil sayısı arasındaki ilişki özellikle son yıllarda birçok çalışmaya konu olmuş, fakat tartışmalı sonuçlar elde edilmiştir (12). Kagi ve arkadaşları, yaptıkları bir çalışmada, periferal eozinofil sayısının, AD’in klinik aktivitesi arasında bir korelasyon olduğunu bildirmişlerdir (13). Biz de yaptığımız bu çalışmada AD’li hastaların serum eozinofil düzeylerinde artış tespit ettik.

AD cinsiyet farkı olmaksızın kız ve erkeklerde eşit sıklıkta görülmekle birlikte, Çin ve İsviçre'de yapılmış bazı çalışmalarda erkeklerde $A D$ sıklığı biraz daha yüksek bulunmuştur (14). Yaptığımız çalışmada $A D$ sıklığı erkeklerde kızlara göre daha fazla rastlandığını tespit ettik.

Plasebo kontrollü çalışmalar orta ve şiddetli tutulumun olduğu AD'li çocuklarda gıda allerjenlerinin deri döküntülerini \%30-40 oranında artırdığını göstermiştir. Üç yaşından sonra gıdaların etkisi azalmaktadır (15). $A D^{\prime}$ in gelişmiş ve gelişmekte olan ülkelerde insidansı giderek artma gösteren ve hem çocuğu hem de ailenin 
yaşam kalitesini etkileyen kronik bir dermatit olması nedeni ile klinik tanı, takip ve tedavisinin dikkatle değerlendirilmesi gerekmektedir (16). AD teşhisi olguların klinik kriterlerin değerlendirilmesi ile konmakta olup kesin tanıyı doğrulayacak bir laboratuar yöntemi bulunmamaktadır (17). T-IgE üretiminin artması, AD'in önemli bulgularından biridir. T-IgE yüksekliği ile deride bulunan lezyonlar arasında belirli bir uyumun olup olmadığı tam olarak gösterilememiştir. Bazı çalışmalar atopik fenotipi ile serum T-lgE seviyesi arasında bir ilişki olduğunu göstermektedir (18). Laske ve Niggemann (18) çalışmalarında AD’in şiddeti ile T-lgE seviyesi arasındaki ilişkiyi araştırmışlar ve anlamlı ilişki saptamışlardır. Özçeker ve ark. yaptıkları çalışmada AD’li hastaların çoğunun serumunda eozinofili ve yüksek serum T-IgE seviyeleri bulmuşlardır (19). Aktaş ve ark. AD’li hastalarda yaptıkları

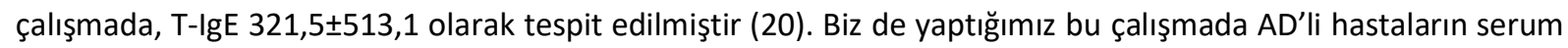
T-IgE düzeylerinde artış tespit ettik.

EKP, eozinofil kaynaklı enflamatuar hastalıkların takip edilmesinde kullanılmaktadır. EKP seviyesi ölçümü vücuttaki birçok sekresyonda belirlenerek immün cevap ölçüm yöntemleri geliştirilmiştir. Alejik rinit veya astım gibi spesifik hastalıklarda EKP seviyesi kan, nazal sekresyon ve akciğer lavaj sıvısında ölçümü yapılabilir. Astım hastalarında yapılan çalışmalarda astım hastalarında periferik kandaki eozinofil miktarı ile EKP seviyesinde uygunluk olduğu gösterilmiştir (21). Biz de yapmış olduğumuz çalışmada AD hastalarında eozinofil düzeylerini artmış olarak bulduk ve kontrol grubu ile karşılaştırdığımızda istatistiksel olarak anlamlı saptadık.

Nötrofil, lenfosit ve trombosit enflamasyon durumlarında görev alan önemli kan parametreleri olup uygulanması ve erişilmesi kolay testlerdir. Günümüzde birçok enfeksiyöz ve tümoral oluşumlarda kullanılmaktadır. NLO yüksek olan hastalarda mortalitenin de yüksek olduğu bazı çalışmalarda tespit edilmiştir (5). Pfada hastalarında yapılan bir çalışmada NLO yüksek ancak istatistiki olarak anlamlı bulunmamıştır (22). Ani işitme kaybı olan hastalarda yapılan bir çalışmada NLO yüksek olduğu ve kontrol grubu ile karşılaştırıldığında istatistiksel olarak anlamlı olduğu ve tedaviye yanıtta bu oranda azalma olduğu tespit edilmiştir (23). Bell palsisi olan hastalarda yapılan çalışmada hastların NLO değerleri kontrol grubu ile karılaştırıldığında istatistiksel olarak anlamlı yüksek olarak bulunmuştur (23). NLO enfeksiyon hastalıklarıiçin olduğu gibi kardiyovasküler hastalıklar için de önemli bir belirteç haline gelmiştir (23). Nazal polipli hastalarda yapılan çalışmada NLO değerleri ile trombosit değerleri yüksek saptandı (24). Kolorektal karsinomlu hastalarda yapılan çalışmada NLO ve TLO değerleri yüksek bulunmuş olup bu tanıyı hastalarda güvenilebilecek prognostik biyobelirteçler olabileceğini gösterdiği tespit edilmiştir (25). Mikrovasküler konplikasyonlu diabetik hastalarda yapılan çalışmalarda kontrol grubuna göre NLO ve TLO değerleri yük olarak bulunmuştur (26). Yaptığımız çalışmada NLO değerlerini kontrol grubuna göre yüksek ve istatiksel olarak anlamlı saptadık.

AD hastalarında T-IgE, eozinofil, NLO, TLO, ELO düzeylerinin yüksek bulunmuştur. Bu parametrelerin bu hastalığın teşhis ve takibinde önemli olduğunu ortaya koymuştur. Bu yüksek değerlerin saptanması daha sonraki çalışmalarda bu değerlerin referans olarak alınabilmesine katkı sağlayacaktır. 


\section{KAYNAKLAR}

1. Boguniewicz M, Leung DY. Atopic dermatitis. In: Adkinson NF, Bochner BS, Busse WW. Middleton's allergy: Principles and practice. 7th ed. Philadelphia: Mosby Elsevier. 2009:1083-9.

2. Hanifin JM. Atopic dermatitis in infants and children. Ped Clin North Am 1991;4:763.

3. Leung DYM. Atopic dermatitis and the immune system: The role of superantigens and bacteria. J Am Acad Dermatol. 2001; 45:13-15.

4. Herrick CA, Xu L, McKenzie AN, Tigelaar RE, Bottomly K. IL-13 is necessary, not simply sufficient, for epicutaneously induced Th2 responses to soluble protein antigen. J Immunol 2003;170:2488-95.

5. Bhat T, Teli S, Rijal J, Bhat H, Raza M, Khoueiry G. Neutrophil to lymphocyte ratio and cardiovascular diseases: a review. Expert Rev Cardiovasc Ther 2013;11:55-9.

6. Elberling J, Linneberg A, Dirksen A, Johansen JD, Frolund L, Madsen F. Mucosal symptoms elicited by fragrance products in a population-based sample in relation to atopy and bronchial hyper-reactivity. Clin Exp Allergy 2005;35:75-81.

7. Lee $\mathrm{CH}$, Chuang HY, Shih CC, Jee SH, Wang LF, Chiu HC. Correlation of serum total IgE, eosinophil granule cationic proteins, sensitized allergens and family aggregation in atopic dermatitis patients with or without rhinitis. J Dermatol 2004;31:784-93.

8. Woerly G, Loiseau S, Loyens M, Schoch C, Capron M. Inhibitory effects of ketotifen on eotaxindependent activation of eosinophils: consequences for allergic eye diseases. Allergy 2003;58:397-406.

9. Czech W, Krutmann J, Schopf E, Kapp A. Serum eosinophil cationic protein (ECP) is a sensitive measure for disease activity in atopic dermatitis. Br J Dermatol 1992;126:351-5.

10. Schultz Larsen FV, Holm NV. Atopic dermatitis in a population based twin series: Concordance rates and heritability estimation. Acta Derm Venereol Suppl 1985;114:159.

11. Yuksel H, Can D, Reisli I, Uzuner N, Orhan F, Cevit O.Characteristics and prognosis of childhood atopic dermatitis: A multicenter study in Turkey. Int Arch Allergy Immunol 2010;152(4):362-7.

12. Nishimoto M, Numahara T, Nakashima K, Yoshida T. Peripheral eosinophil counts relates the improvement of the skin lesions of atopic dermatitis patients more sensitive thanserum eosinophil cationic protein levels. Arerugi 1998;47:591-6.

13. Kagi MK, Joller-Jemelka H, Wuthrich B. Correlation ofeosinophils, eosinophil cationic protein, and soluble interleukin-2 receptor with the clinical activity of atopic dermatitis. Dermatology 1992;185:8892.

14. Gu H, You LP, Liu YS. Survey on the prevalance of childhood atopic dermatitis in ten cities of China. Chin J Dermatol 2004;37:29-31.

15. Nationale Eczema Society 2003. Diet and Eczema in Children. www.eczema.org/ 10/9/20046. 
16. Ben-Gashir MA, Sedd PT. Hy RJ. Quality of life and disease severity are correlated in children with atopic dermatitis. Br J Dermatol 2004;150:284-90.

17. Wollenberg A, Wetzel S, Burgdorf WHC, Haas J. Viral infections in atopic dermatitis: pathogenic aspects and clinical management. J Allergy Clin Immunol 2003;112:667-674.

18. Laske N, Niggemann B. Does the severity of atopic dermatitis correlate with serum Ig E levels? Pediatr Allergy Immunol 2004;15:86-8.

19. Deniz Özçeker, Cansu Durak, Aslı Derya Kardelen, Nermin Güler, Zeynep Tamay. Çocuklarda Atopik Dermatit: Ne Kadar Atopik? Asthma Allergy Immunol. 2017;15:135-139.

20. Belgin Aktaş, Yakup Canıtez, Nihat Sapan. Atopik dermatit tanı yaşının ek alerjik hastalık gelişimi üzerine etkisi. Türk Ped Arfl 2011;46:308-12.

21. Frigas E, Gleich GJ. The eosinophil and the pathophysiology of asthma. J Allergy Clin Immunol 1986;77:527-37.

22. Kayabaşı S, Gül F. Pfapa sendromunda yeni öngörücü parametreler: nötrofil lenfosit oranı ve trombosit lenfosit oranı. Ortadogu Tıp Derg 2019;11(3):231-234.

23. Bucak A, Ulu S, Oruc S, Yucedag F, Tekin MS, Karakaya F. Neutrophil-to-lymphocyte ratio as a novelpotential marker for predicting prognosis of Bell palsy. Laryngoscope 2014;124:1678-81.

24. Doğan Atan, Kürşat Murat Özcan, Sabri Köseoğlu, Aykut İkincioğulları, Mehmet Ali Çetin, Serdar Ensari. Nazal polipte yeni öngörücü parametreler: Nötrofil lenfosit oranı ve trombosit lenfosit oranı. Kulak Burun Bogaz Ihtis Derg 2015;25(2):97-101.

25. Utku Oflazoğlu, Ahmet Alacacıoğlu, Işıl Somalı, Melike Yüce1, Abdullah Murat Buyruk, Umut Varol. Nötrofil/Lenfosit Oranı, Trombosit/Lenfosit Oranı ve Ortalama Trombosit Hacminin Kolorektal Karsinomlu Hastalardaki Prognostik Değeri Acta oncologia turcica. 2017;50(1):1-6

26. Gülşah Şiranlı, Cuma Mertoğlu, Alevtina Ersoy, Yücel Karakurt, Adalet Özçiçek. Diyabetik mikrovasküler komplikasyonlarda nötrofil lenfosit oranı ve ortalama trombosit hacmi. Ulusal 2. Kalıtsal Metabolik Hastalıklar laboratuvar Sempozyumu. 2019;PS-04. 